\title{
TÓPICOS ESPECIAIS A RESPEITO DA RETÓRICA CLÁSSICA ${ }^{1}$
}

Profa. Dra. Luciene de Lima Oliveira (UERJ)

RESUMO: Para obter a persuasão de seus semelhantes, o homem busca meios de aperfeiçoar a linguagem, a fim de que outros componentes da sociedade sejam influenciados e, por conseguinte, convencidos, de modo a criar uma cumplicidade entre ambos: o enunciador / o enunciatário. O uso da retórica é uma constante na história das sociedades as mais diversas. Os homens, ao interagirem, empregaram a linguagem de modo eloquente, buscando se entender e conseguir o assentimento uns dos outros, antes mesmo da existência de tomarem a si a tarefa de ensinar, elaborar teorias e escrever obras de retórica. Desse modo, o presente artigo tem por escopo tecer comentários sobre as possíveis origens e funções da retórica, além de outras informações como, por exemplo, a relação entre a retórica e o cristianismo.

PALAVRAS-CHAVE: 1. Retórica; 2. Persuasão; 3. Discursos; 4. Cristianismo

\section{SPECIAL TOPICS CONCERNING CLASSICAL RHETORIC}

ABSTRACT: To obtain the persuasion of their equals, man searches for means of perfecting language so that other components of society are influenced and, consequently, convinced, and it generates complicity between both the enunciator and enunciatee. The use of rhetoric is a constant in the history of many diverse societies. Men, when interacting, used language in an emphatic way, trying to understand themselves and get others' approval even before the existence of the appropriation of the task of teaching, elaborating theories and writing rhetorical works. Thus, this article presents as scope the action of commenting on the possible origins and functions of rhetoric, besides other information, such as the relation between rhetoric and christianity.

KEYWORDS: 1. Rhetoric; 2. Persuasion; 3. Speeches; 4. Christianity

\footnotetext{
${ }^{1} \mathrm{O}$ presente artigo constitui um resumo e uma adaptação do capítulo 3 da tese de doutorado intitulada $O s$ Discursos Epidícticos de Paulo de Tarso no Livro dos Atos dos Apóstolos (Tradução e Comentários), defendida em fevereiro de 2016, sob a orientação do Prof. Dr. Auto Lyra Teixeira no PPGLC da UFRJ.
} 
[255] (...) Com (a palavra), refutamos os maus e elogiamos os bons. Através da palavra, instruímos os incultos e provamos os sensatos. De fato, criamos a palavra como um sinal mais importante que é necessário para a boa reflexão. E uma palavra verdadeira tanto conforme a lei quanto conforme a justiça é imagem de uma alma nobre e crível. [256] Com a palavra, também discutimos a respeito dos assuntos duvidosos e investigamos a respeito dos assuntos desconhecidos. Quanto às crenças, as quais, quando falamos, persuadimos os outros, necessitamos dessas mesmas (crenças), quando deliberamos e chamamos retóricos aqueles que são capazes de falar à multidão, mas consideramos aqueles que discutem, muito bem, com eles mesmos, a respeito das atividades. [257] Em resumo: se é necessário (expor) sobre o poder desta palavra, reconheceremos que nada, que foi terminado por meio da inteligência, foi feito em silêncio, mas também (quanto mais) formos possuidores da reflexão, temos (mais) necessidade dela (= da palavra).

(ISOCRATES. Antidosis, 255-257)

O vocábulo "retórica" - rhetoriké2 - provém do radical grego de rhé-tor ${ }^{3}$, "aquele que fala em público", de onde “orador em assembleia, homem político" (CHANTRAINE, 1970, p. 326) -, significando o "que concerne aos oradores ou a arte oratória, de onde orador" (BAILLY, 2000, p. 1718).

A linguagem é inerente ao homem, o que o permite pensar, agir e viver em sociedade. Sem a posse da linguagem, o ser humano não saberia como entrar em contato com o outro, como estabelecer vínculos psicológicos e sociais com esse outro que é, simultaneamente, semelhante e diferente. A linguagem, talvez, seja o primeiro poder do homem. Todavia, esse poder da linguagem é o próprio homem que constrói e que ajusta por meio de suas trocas, seus contatos no decorrer da história dos povos. A argumentação é um setor de atividade da linguagem que sempre exerceu fascínio. Desde a retórica dos antigos, fizeram dela o próprio fundamento das relações pessoais ( $a$ arte de persuadir) (CHARAUDEAU, 2010, p. 7).

Como pontua Reboul "a melhor introdução à retórica é sua história” e oferece algumas ressalvas: a retórica é anterior à sua própria história, uma vez que é inconcebível que os homens não tenham se utilizado da linguagem a fim de obter a persuasão. $O$ pesquisador sublinha que se pode encontrar a retórica entre povos, tais como os hindus, os chineses, os egípcios e os hebreus. Mesmo assim, em certo sentido,

\footnotetext{
${ }^{2} \mathrm{Na}$ verdade, esse vocábulo faz parte de um adjetivo triforme rhetorikós, -ké, -kón. Ressalte-se que o sufixo nominal -ikós indica aptidão, capacitação, isto é, "apto, capaz de falar".

${ }^{3}$ Rhétor constitui um termo mais usual que rhetér (CHANTRAINE, 1970, p. 326). O vocábulo rhétor: possui como raízes verbais $e r$-, rhe-, "falar", seguido do sufixo -tor que indica o agente da ação.
} 
pode-se afirmar que a retórica foi uma invenção grega, tal qual a geometria, a tragédia, a filosofia (REBOUL, 2004, p. 1).

Cícero (106-43 a.C.) dá o seguinte testemunho a respeito de a retórica provir da eloquência:

Verum ego hanc uim intellego esse in praeceptis omnibus, non ut ea secuti oratores eloquentiae laudem sint adepti, sed, quae sua sponte homines eloquentes facerent, ea quosdam observasse atque id egisse; sic esse non eloquentiam ex artificio, sed artificium ex eloquentia natum (CICERON, De l' Orateur, I, XXXII apud PETERLINI, 2004, p. 120).

Mas creio que nesses preceitos (dos retores) existe uma força, não tal que por havê-la seguido os oradores tenham alcançado a glória da eloquência, mas acho que alguns observaram e praticaram o que homens eloquentes faziam por instinto. Não foi assim a eloquência que nasceu da retórica, mas a retórica, da eloquência.

Quando se fala sobre os primórdios da retórica, os primeiros nomes que se tem referência são os de Córax e Tísias. Há uma antiga tradição de que a arte da retórica seria uma invenção de ambos no século V a.C. em Siracusa, na Sicília ${ }^{4}$; de Siracusa ela teria passado a Atenas através do sofista Górgias de Leontinos.

Assim é que atribuem a Córax e Tísias um tratado sobre a retórica, mas que não chegou até a posteridade. Esse tratado era de caráter judicial, uma vez que instruía os advogados de como obter vitória em suas causas perante os tribunais. Tem-se, então, uma origem judiciária da retórica.

A pesquisadora María Colombani destaca que o "o discurso se inscreve em um terreno agonístico, porque se luta palavra com palavra, cuja preeminência é extraordinária. O orador é um agonistés, um combatente e o discurso possui um télos, um fim: convencer o auditório"5 (COLOMBANI, 2002, p. 251).

A propósito, antes de Córax e Tísias, considera-se que os discursos da Ilíada e da Odisseia tenham servido como paradigma aos jovens, enquanto, possivelmente, os textos teóricos da retórica eram inexistentes. Acredita-se que a retórica seja uma disciplina oral muito antiga no mundo ocidental.

Luiz Rhoden sublinha que "a Ilíada e a Odisseia de Homero são consideradas obras monumentais da eloquência grega. Com ele, "mestre universal", os gregos

\footnotetext{
${ }^{4}$ Deve-se destacar que vários sicilianos haviam perdido suas propriedades para os tiranos; assim, sem o poderio militar, os sicilianos tiveram que desenvolver a eloquência para reaverem seus bens confiscados pelos tiranos. Supõe-se que, em Siracusa, ocorriam muitos debates políticos.

${ }^{5}$ Tradução da autora.
} 
aprendiam a gramática, a história, a moral e a arte de bem falar" (RHODEN, 1997, pp. 20-21).

Atestam-se, na Ilíada, pequenos discursos que eram pronunciados nas assembleias deliberativas: "Nestor se levantou, doce no falar, orador eloquente de Pílio; sua voz fluía mais doce que o mel” (HOMÈRE. Iliade I, vv. 247-249). Com isso, pensase que os gregos já organizavam seus discursos em tempos bem remotos, destacando, desse modo, a supremacia do lógos ${ }^{6}$, da palavra.

Convém citar também o discurso de Crises diante dos guerreiros aqueus. Ora, com o discurso do sacerdote de Apolo, se instaura o agón verbal entre ele e os heróis gregos:
Atridas e também outros Aqueus de belas grevas, que os deuses, moradores do Olimpo, ofereçam a vós, após terem destruído a cidade de Príamo, um bom retorno para casa. Ora, libertai para mim a querida filha, aceitai os resgates, temendo o filho de Zeus, Apolo certeiro no tiro.

(HOMÈRE. Iliade I, vv. 17-21)

Têm-se, ainda, como modelos de eloquência, os discursos de três guerreiros gregos: Odisseu (HOMÈRE. Iliade IX, vv. 223-307), Fênix (HOMÈRE. Iliade IX, vv. 431-606) e Ájax, Telamônio (HOMÈRE. Iliade IX, vv. 622-642). Esses discursos tinham por objetivo persuadir Aquiles a retornar ao campo de batalha.

É bom lembrar que a eloquência também fazia parte da educação de Aquiles (HOMÈRE. Iliade IX, 440-443).

$\mathrm{Na}$ Odisseia, a eloquência era considerada um presente divino (HOMER. Odyssey 8, vv. 167-172).

Os gregos antigos acreditavam que o discurso era provido de poder; esse poder, os gregos pensavam que emanava de uma divindade: - a Peithó - "a Persuasão".

\footnotetext{
${ }^{6}$ É bom lembrar que lógos é um substantivo deverbal, oriundo de légo, "falo", não obstante, esse verbo, em seu sentido original, possuir o significado de: "reunir, colher, selecionar" (HOMĖRE. Iliade XXIII, v. 239; XXI, 27); de onde se tem também o significado de "contar, calcular, enumerar" (HOMÈRE. Iliade II, v. 125). A propósito, lógos, "palavra", possui, igualmente, alguns significados; citem-se, por exemplo: "conta, consideração, explicação, raciocínio, razão" etc. Sublinhe-se que, na "teologia cristã", o vocábulo designa a segunda pessoa da Trindade (CHANTRAINE, 1970, p. 625). Por outro lado, Maria Helena da R. Pereira lembra que a forma plural, lógoi, significa "narrativas" (HOMÈRE. Iliade XV, v. 393) ou "argumentos" (HOMER. Odyssey 1, 56), dependendo do contexto; ora, lógoi foi também a terminología de que se valeu Heródoto para fazer referência "ao conjunto ou a partes da sua obra ou a qualquer das muitas lendas que nela intercala" (PEREIRA, 1993, pp. 256-257).
} 
O tragediógrafo grego Ésquilo, através da fala da deusa Atená, faz referências à "Persuasão". A deusa acreditava que era a Peithó quem fazia as suas palavras parecerem "mágicas e doces': "doçura da minha língua e encanto" (AESCHYLUS. Eumenides v. 886). Em outra ocasião, a filha de Zeus mostra-se agradecida à Peithó por guiar a sua voz e os seus lábios: "Agradeço à Peithó, cujos olhos me vigiavam a língua e a boca" (AESCHYLUS. Eumenides v. 970). E, ainda, convém lembrar o que Odisseu falou a Neoptólemo: “Agora, segundo a experiência, vejo que, entre os mortais, a língua, não as ações, conduz todas as coisas" (SOPHOCLES. Philoctetes vv. 98-99).

A preocupação com o uso da linguagem para se expressar de maneira clara e concisa é uma herança clássica que passou para a cultura ocidental. Assim, testemunha Romilly:

\begin{abstract}
Essa eloquência, tão importante na cultura dos antigos, está, de fato, no tocante a Atenas e às obras conservadas, inteiramente, contida nos limites do século IV. Fosse ela judiciária ou política, a eloquência ática fulgurou entre o fim da guerra do Peloponeso e a morte de Alexandre. Houve, evidentemente, grandes oradores antes do século IV; suas obras, porém, não se conservaram, e os discursos reescritos por Tucídides ${ }^{7}$ à sua maneira mal podem dar uma ideia delas. No terreno da eloquência política, nada temos antes de Demostenes, cuja atividade começa em meados do século IV. As circunstâncias são um pouco mais favoráveis na esfera judiciária; Andocides e Lísias se situam no encontro dos séculos V e IV ${ }^{8}$ (ROMILLY, 1980, pp. 148-149).
\end{abstract}

Atribui-se a Aristóteles - filósofo do século IV a.C. - uma teoria mais sistemática sobre os gêneros e sobre a natureza do discurso. O filósofo escreveu dois livros que versam sobre o discurso: He Poietikè tékhne (A Arte Poética) e He Retorikè tékhne (A Arte Retórica).

Quando Isócrates fundou sua escola de retórica, os sofistas eram os mestres da retórica que ensinavam a eloquência, preocupando-se estritamente com a eficácia do discurso, independentemente da causa a defender. Os sofistas tinham por escopo a formação de jovens na arte de manejar argumentos e, com isso, prepará-los para a vida de cidadãos; seus ensinamentos eram muito dispendiosos. Não obstante, Detienne

\footnotetext{
${ }^{7}$ Convém lembrar que Tucídides, em sua obra historiográfica, reproduziu determinados discursos, tal qual o escritor dos Atos; citem-se, por exemplo: os discursos dos corcireus aos atenienses (THUCYDIDE. La Guerre du Péloponnèse I, 32 a 36), os discursos dos coríntios, também aos atenienses (THUCYDIDE. La Guerre du Péloponnèse I, 37 a 43), e o famoso discurso de Péricles, que ficou conhecido como "O Discurso Fúnebre de Péricles" (THUCYDIDE. La Guerre du Péloponnèse II, 3446). Sublinhe-se que, de um modo geral, os discursos reproduzidos pelo historiador são classificados em deliberativos.

${ }^{8}$ Todas as datas deste excerto se referem a a.C..
} 
salienta que as relações sociais são dominadas pela palavra; o sofista e o retórico são ambos técnicos do lógos (DETIENNE, 2013, p. 130).

Górgias de Leontinos (485-380 a.C.), considerado como um dos fundadores do discurso epidíctico, cria uma prosa eloquente, com o emprego das muitas figuras. Por meio de Górgias aparece, então, a retórica como estética e, particularmente, literária. Levando isso em consideração, Reboul ressalta: "Isso porque até então os gregos identificavam "literatura" com poesia (épica, trágica). A prosa, puramente funcional, restringia-se a transcrever a linguagem oral comum" (REBOUL, 2004, p. 4). Tem-se, então, uma origem literária da retórica.

Considera-se que a ligação entre a sofística e a retórica aparece, de modo pleno, em Protágoras (486-410 a.C.), que ensinava, simultaneamente, a eloquência e a filosofia. Protágoras ensinou uma técnica denominada de erística (eristiké, provém de éris, "controvérsia, disputa"), onde parte do pressuposto de que todo argumento se opõe a outro, podendo qualquer tese ser sustentada ou refutada. Essa técnica seria uma espécie de arte de sobrepujar uma discussão contraditória.

O discurso não pode mais pretender ser verdadeiro, nem mesmo verossímil, só poderá ser eficaz; em outras palavras, próprio para convencer, o que, no caso, equivale a vencer, a deixar o interlocutor sem réplica. A finalidade dessa retórica não é encontrar o verdadeiro, mas dominar através da palavra; ela já não está devotada ao saber, mas sim ao $\operatorname{poder}^{9}$ (REBOUL, 2004, p. 10).

Destacam-se, nesse contexto, os dissoì lógoi, "discussões/argumentos duplos", num tratado sofístico anônimo de técnicas argumentativas; os argumentos duplos baseiam-se na oposição entre duas diferentes teses a respeito de um mesmo tema. Esse tratado foi adicionado aos escritos de Sexto Empírico (séculos II-III a.C.). Não se sabe, ao certo, por que o tratado foi atribuído a esse filósofo grego. Costuma-se fixar a data da sua composição em torno de 404 a.C. Nove suscintos capítulos compõem o dissoì lógoi de temáticas variadas, tais como, a respeito do bom e do ruim, do bonito e do feio, do justo e do injusto, da verdade e da falsidade, da sabedoria e da excelência, se essas coisas podem ser ensinadas etc.

\footnotetext{
${ }^{9}$ Convém citar Eurípides: Isto que destrói, completamente, as cidades bem habitadas e as casas dos mortais: os belos discursos; de fato, não convém falar algo encantador aos ouvidos, mas o que traz boa fama (EURIPIDES. 


\section{Como destaca Romilly:}

Com efeito, na cidade democrática, cidadãos em número cada vez maior podiam, pela influência da palavra, participar da sua administração. A antiga educação aristocrática já não bastava, então, nem tampouco bastavam as virtudes tradicionais. A arte de falar na assembleia, de argumentar sobre política, ou seja, a "arte política" é o objeto do novo ensino (ROMILLY, 1980, p. 128).

Reboul sublinha que Isócrates integra a filosofia no discurso, uma vez que: "Ela (a filosofia) é para a alma o que a ginástica é para o corpo, formação intelectual e moral, boa para os jovens, mas inútil para perseguir por toda a vida (...). Em suma, para Isócrates, "filosofia" é cultura geral, centrada na arte oratória; numa palavra: retórica" (REBOUL, 2004, p. 12).

Isócrates insiste que os requisitos para ser um bom orador são, de um modo geral, a disposição natural e a praticidade, além de um ensino sistemático:

Se é preciso não só acusar os outros mas também expor o próprio pensamento, penso que todos aqueles que são bem sensatos vão concordar comigo: muitos dos que se dedicaram à filosofia continuaram sendo simples, mas outros, sem jamais terem frequentado alguns dos sofistas, se tornaram extraordinários ao falar e governar. Pois a capacidade dos discursos e de todas as outras ações aparece entre os dotados de boas disposições naturais e naqueles que se exercitaram com respeito à prática. (ISOCRATES. Against the Sophists 13. 14).

A relação entre Isócrates e Platão é explicitada por Marrou do seguinte modo: "Se a educação platônica funda-se, em última análise, na noção de Verdade, a educação isocrática repousa na exaltação das excelências da palavra, ou melhor, do Lógos" (MARROU, 1969, p. 134). Marrou prossegue o seu pensamento nos seguintes termos:

O progresso da civilização e da cultura helênicas passou a requerer melhor educação: a revolução pedagógica iniciada pelos sofistas, na segunda metade do século, culminou com a obra de dois grandes educadores: Isócrates, cuja carreira no ensino se prolongou de 393 a 338 a.C., e Platão que ensinou desde 387 até 348 . A competição entre suas escolas rivais, eventualmente, estruturou as duas formas que daí por diante viriam a tomar a alta cultura grega - uma, a oratória; outra, a filosófica. Foi uma frutífera rivalidade (ibidem, p. 216). 
Na Paideia Helenística, o tratado retórico de Aristóteles, que servira de paradigma para os retores, agora, seria desenvolvido minuciosamente.

Cícero é considerado como um dos oradores romanos mais profícuos de seu tempo; foi para a Grécia dar continuidade à sua formação retórica e filosófica ${ }^{10}$ :

Cícero defendia a ideia de que um bom orador era aquele que detinha um amplo conhecimento em todas as ciências e de todos os grandes reveses da vida (CICÉRON. De Oratore 1. 20, 1. 72). E ainda: o orador deveria ter formação filosófica (CICÉRON. De Oratore 1. 46). Assim, com Cícero houve uma aproximação entre Filosofia e Retórica, uma vez que se percebe a importância dada pelo orador latino ao estudo da filosofia. Segundo ele, a eloquência não é extraída da oratória, mas da filosofia (CICERO. Orator 3.12).

As obras De Oratore (“Do Orador”) (55 a.C.) e Orator (“O Orador”) de Cícero (46 a.C.) e a Instituto Oratoria ("Instituição Oratória") (93 d.C.) de Quintiliano são consideradas importantes tratados de retórica latina. Diferentemente dos gregos, os romanos possuíam advogados, que não recebiam por seus serviços, mas apenas presentes. De acordo com Reboul, "Cícero e Quintiliano foram ambos grandes advogados que, em seus livros, “teorizaram” sobre sua prática” (REBOUL, 2004, pp. 71-72).

Todavia, enquanto na Grécia os jovens, já no século IV a.C., frequentavam as escolas dos sofistas, onde se adestravam em política, moral e retórica; enquanto, aproximadamente, por 339 a.C., Aristóteles nos legava sua Arte Retórica. Mas é claro que os romanos acabariam por adotar a retórica, a "esse" poder extraordinário sobre as pessoas, essa faculdade, no dizer de Aristóteles, capaz de descobrir todos os possíveis meios persuasivos sobre qualquer assunto. (Ret. I, 25-26 e 3132) (PETERLINI, 2004, p. 121)

Reboul enfatiza que há um grande problema que surgiu no fim da antiguidade: a relação entre a retórica e a nova religião, isto é, o cristianismo. A nova crença se

\footnotetext{
${ }^{10}$ Mesmo que o discurso seja particular, a escolha apropriada e certa das palavras ao se elaborar um discurso, para um determinado fim, era vista como uma técnica importante. Os gregos intitulavam isso de heúresis, "descoberta"; os romanos, de inventio. A retórica latina traduziu determinados termos gregos, tais como: metaphorá é denominada de tralatio; epideiktikón, demonstrativum; tékhne rhetoriké, ars oratória ou rhetorica. É bom sublinhar que o vocábulo grego rhetér apresentará duas possibilidades de tradução: orator, que é aquele que elabora os discursos, e rhetor, que era o docente, normalmente grego (REBOUL, 2004, pp. 71-72).
} 
caracteriza em uma ruptura total com a cultura antiga, cujo "cerne" é formado pela retórica, associada a uma cultura pagã, idólatra e imoral. Para os cristãos, havia o perigo de essa cultura afastar os fiéis da redenção, "única coisa necessária".

Quando todas as estruturas administrativas do Império caíram, foi, justamente, a Igreja que se tornou depositária da cultura antiga, incluindo a retórica. Não se deve esquecer que a maioria dos pais da Igreja rejeitaram os autores pagãos, uma vez que os consideravam como inúteis e perigosos; mas admitiam a língua e a retórica dos pagãos.

A primeira razão justifica-se pelo fato de que a Igreja, em seu papel missionário e em suas polêmicas, não poderia prescindir da retórica, nem ao menos da língua grega ou latina. Não era recomendável deixar os meios de persuasão e de comunicação em mãos de adversários. É bom lembrar o que Santo Agostinho, no fim do século IV d.C., sublinhou sobre a necessidade da prática da retórica:

É um fato, que pela arte da retórica, é possível persuadir o que é verdadeiro como o que é falso. Quem ousará, pois, afirmar que a verdade deve enfrentar a mentira com defensores desarmados? Seria assim? Então, esses oradores, que se esforçam para persuadir o erro, saberiam desde o proêmio conquistar o auditório, torná-lo benévolo e dócil, ao passo que os defensores da verdade não o conseguiriam? (AGOSTINHO. A Doutrina Cristã IV, 2, 3).

A segunda razão pontua que não se deve negar que a própria Bíblia é, essencialmente, retórica, com metáforas, alegorias, jogos de palavras, antíteses, argumentações etc.

Reboul destaca que, ao mesmo tempo que a Bíblia era um modelo, ela constituía também um problema. De fato, não bastava que ela fosse lida, mas também compreendida. A propósito, para interpretá-la, utilizar todos os recursos retóricos nunca era excessivo (REBOUL, 2004, pp. 77-78). O pesquisador chama assim a atenção para o fato de que "mais tarde, na era cristã, o gênero epidíctico será enriquecido com toda a pregação religiosa" (ibidem, p. 47).

É apropriado citar também Marrou quanto ao "embate" entre a retórica e a nova crença:

$\mathrm{Na}$ antiguidade, a conversão ao cristianismo exigia, da parte de um homem culto, um esforço de renúncia, de superação: era-lhe necessário confessar a vaidade radical, admitir os limites desta cultura de que, até então, ele havia vivido. Os cristãos dos primeiros séculos estavam, de 
fato, perfeitamente conscientes desta oposição: Quid Athenae Hierosolymis ..."Que há de comum entre Atenas e Jerusalém, entre a Academia e a Igreja?" 11 (MARROU, 1969, p. 488).

\section{É bom lembrar que os relatos bíblicos possuem referências aos homens aquinhoados com a eloquência, tais como Arão, Davi e os da tribo de Naftali ${ }^{12}$ :}

[10] E Moisés disse ao Eterno: Rogo, Senhor! Eu não sou homem eloquente nem de ontem, nem de anteontem, nem desde que falaste a teu servo, pois tenho fala lenta e língua trêmula. [11] E o Eterno disse para ele: Quem coloca a boca no homem? Ou quem o faz ser mudo ou surdo, ou enxergar ou ser cego? Acaso não sou Eu, o Eterno? [12] E agora, vai-te, e Eu estarei com a tua boca e te ensinarei o que hás de falar. [13] E disse: Rogo, Senhor! Envia por meio de quem hás de enviar! [14] E a ira do Eterno acendeu-se com Moisés, e disse: Certo! Aarão [Aharon], teu irmão, o levita, eu sei que ele falará. E também, eis que ele está saindo ao teu encontro, e te verá e se alegrará em seu coração. (Ex 4. 10-14)

Quanto a Davi e à tribo de Naftali, tem-se o seguinte testemunho: "E respondeu um dos moços, dizendo: "Eis que vi um filho de Ishai, de Bet-Léhem, que sabe tocar, e é valente e homem guerreiro e prudente em palavras e de boa aparência, e o Eterno está com ele" (1 Sm 16. 18); "Naftali é uma gazela solta, que proferirá belas palavras" (Gn 49. 21).

\footnotetext{
11 In: TERTUllian. Prescription Against Heretics, 7. Este livro constitui um tratado, tendo, por destinatários, os filósofos e os hereges, sendo a filosofia considerada um canal para as heresias. O teólogo, para fundamentar o seu pensamento, faz citações das epístolas paulinas (1 Tm 1.4; 4.1; 2 Tm 2. 17; Tt 3.9). Ora, o Espírito diz, explicitamente, que, nos últimos tempos, alguns apostatarão da fé, dedicando-se a espíritos mentirosos e a ensinos de demônios (1 Tm 4.1).

${ }^{12}$ É interessante destacar também os seguintes discursos atestados no Antigo Testamento: o discurso da mulher sábia de Técoa diante do rei Davi e os quatro discursos de Moisés. Segue-se, primeiramente, o discurso da mulher de Técoa: ${ }^{12} \mathrm{E}$ a mulher disse: Peço-te que a tua serva fale uma palavra ao rei, meu Senhor - e ele disse: Fala. ${ }^{13} \mathrm{E}$ a mulher disse: Por que pensas tu tal coisa contra o povo de Deus? Pois ao falar o rei esta coisa fica como culpado, visto que o rei não torna a trazer o seu desterrado (Avshalom). ${ }^{14}$ Porque, certamente, morreremos, e seremos como águas derramadas na terra, que jamais tornarão a se ajuntar, e Deus não favorecerá ninguém para não lhe tirar a vida, mas, sim, cogitará pensamentos, para que não se desterre Dele o seu desterrado. ${ }^{15} \mathrm{E}$ se eu vim, agora, falar esta palavra ao rei, meu Senhor, é porque o povo me atemorizou, mas a tua serva disse: Falarei ao rei; talvez o rei faça segundo a palavra da sua serva. ${ }^{16}$ Porque o rei ouvirá, para livrar a sua serva da mão do homem que pretende destruir a mim, junto com meu filho, da herança de Deus. ${ }^{17} \mathrm{E}$ tua serva disse: Seja, agora, a palavra do rei, meu senhor, para descanso, porque como um anjo de Deus, assim é o rei, meu senhor, para ouvir o bem e o mal, e o Eterno, teu Deus, será contigo (2 Sm 14. 12-17). Tem-se, igualmente, os quatro discursos de Moisés (Dt capts. 1 e 4.1-43; 4. 44-49; capt. 26; capts. 27-30), eis, somente, alguns excertos: ${ }^{5}$ Além do Jordão, na terra de Moav, Moisés começou a explicar esta Torá, dizendo: ${ }^{6} \mathrm{O}$ Eterno, nosso Deus, nos falou em Horeb, dizendo (...) (Dt 1. 5-6); ${ }^{1}$ E agora, ó Israel, ouve os estatutos e os juízos que eu vos ensino para os cumprirdes, a fim de que vivais, entreis e herdeis a terra que o Eterno, Deus de vossos pais, vos dá. ${ }^{2}$ Não acrescentareis sobre a coisa que eu vos ordeno, e não subtraireis dela, para que guardeis os preceitos do Eterno, vosso Deus, que eu vos ordeno (...) (Dt 4. 1-2).
} 
Florescu destaca que o hebraico é considerado por ter a qualidade de ser claro, como um resultado da unidade política, cultural e religiosa dos indivíduos (FLORESCU, 1982, p. 11): "Pois não foste enviado a um povo cujo idioma não compreendes ou cuja língua é difícil, mas, sim, à Casa de Israel” (Ez 3. 5).

Os hebreus acreditavam que a palavra da Deidade era revestida de poder assim que fosse emitida, não retornando vazia, sem efeito (Is 55. 11). A palavra de Jeová era tal qual uma flecha que, assim que era atirada do arco, não poderia mais voltar. Então, a palavra divina nunca falhava, mas cumpria e completava os seus propósitos, além de ser uma palavra "pura", "refinada" e "eterna" (S1 12. 7; Is 40. 8). Havia a crença também, entre os hebreus, que as palavras retas eram persuasivas (Jó 6. 25) e que "meras palavras” levavam à penúria ( $\mathrm{Pv}$ 14. 23). Ressalte-se que há mandamentos para ter cuidado com aquilo que se falava (S1 34. 13-14 ${ }^{13}$; Pv 18. 21).

Na década de 60, estudos importantes a respeito da retórica foram atestados. De um lado, tem-se Charles Perelman e L. Olbrechts-Tyteca, ${ }^{14}$ que viram a retórica como "arte de argumentar", isto é, a retórica visa a convencer. Geralmente, extraem, por um lado, seus exemplos entre os oradores de diversas áreas, tais como, religiosos, jurídicos, políticos e filosóficos. Por outro lado, Morier, G. Genette e J. Cohen, entre outros, veem a retórica como um "estudo do estilo", e, principalmente, das "figuras". A retórica constituiria tudo aquilo que tornaria literário um determinado texto. A retórica, então, inicialmente, para o primeiro grupo, era vista como persuasão e, para o segundo, como estilo.

Reboul conceitua a retórica nos seguintes termos: "retórica é a arte ${ }^{15}$ de persuadir pelo discurso" (REBOUL, 2004, p. XIV). Eis a definição de Reboul para “discurso", subscrita do seguinte modo:

Por discurso, entendemos toda produção verbal escrita ou oral, constituída por uma frase ou por uma sequência de frases, que tenha

\footnotetext{
$13{ }^{13}$ Quem é o homem que ama a sua vida e deseja longos dias para aproveitá-la em felicidade? ${ }^{14}$ Aquele que guarda do mal a sua língua e cujos lábios não pronunciam falsidades (S1 34. 13-14).

${ }^{14}$ Chaïm Perelman e Lucie Olbrechts-Tyteca - dois dos mais importantes teóricos da retórica do século XX -, tendo por base Aristóteles, escrevem o Tratado da Argumentação. Nascia assim, o que se denomina, hoje, de "A Nova Retórica".

15 Reboul lembra que há uma eminente discussão a respeito da retórica, se ela é uma tekhné com "habilidade inata" ou "adquirida": "Esta, dizíamos, é uma arte. Este termo, tekhné, é ambíguo, e até duplamente ambíguo. Em primeiro lugar, porque designa tanto uma habilidade espontânea quanto uma competência adquirida através do ensino. Depois, porque designa ora uma simples técnica, ora, ao contrário, o que na criação ultrapassa a técnica e pertence, somente, ao "gênio" do criador. Em qual ou em quais desses sentidos se está pensando quando se diz que a retórica é uma arte? Em todos." (REBOUL, 2004, p. XXI).
} 
começo e fim e apresente certa unidade de sentido. (...) Conforme nossa definição, a retórica não é aplicável a todos os discursos, mas somente àqueles que visam a persuadir, o que de qualquer modo representa um belo leque de possibilidades! Enumeremos as principais: pleito advocatício, alocução política, sermão, folheto, cartaz de publicidade, panfleto, fábula, petição, ensaio, tratado de filosofia, de teologia ou de ciências humanas. Acrescente-se a isso o drama e o romance, desde que de "tese", e o poema satírico ou laudatório (ibidem, p. XIV).

Cite-se, agora, a definição de Aristóteles para a retórica: "a retórica é a capacidade de examinar aquilo que seja passível de persuasão no que diz respeito a cada (situação)” (ARISTOTE. Rhétorique I, 2, 1355 b 25-34).

Molinié, igualmente, sublinha que a retórica é uma prática definida, de um modo geral, como a "arte de persuadir". O meio da persuasão é a linguagem, incluindo a totalidade dos seus componentes, sendo a palavra individual a mais viva e poderosa. Esta palavra é considerada como um todo orquestral: as frases que se pronunciam com as palavras e as expressões pelas quais se optam, a voz, o olhar e os gestos, as informações que são dadas (...). O mundo da retórica é o da vida, do movimento, das comunicações e das relações sociais. A persuasão consiste do ponto de vida daquele que fala para agir sobre os destinatários de seu discurso, para que esses tenham uma opinião, um sentimento, uma vontade (MOLINIÉ, 1992, pp. 5-6). A persuasão, então, consistiria em levar alguém a crer em alguma coisa.

Já Heinrich destaca que a retórica é definida como ars bene dicendi, "arte de falar bem", sendo que bene é a virtus específica do discurso partidário constituída pelo sucesso da persuasão. Esta virtus geral do discurso realizar-se-á, especificamente, em cada fase da elaboração e em cada parte do discurso (LAUSBERG, 1967, p. 86).

Reboul destaca, pelo menos, quatro funções da Retórica, isto é, os serviços que são capazes de prestar: a função persuasiva, a hermenêutica, a heurística e a pedagógica (REBOUL, 2004, p. XVII).

Depreende-se que a primeira função da retórica - a função persuasiva - é devido à sua própria definição: a "arte de persuadir". A propósito, esta função é a mais clara e a mais antiga. Os meios para se alcançar a persuasão podem ser de nível racional ou afetivo, pois "em retórica razão e sentimentos são inseparáveis", como sublinha Reboul (ibidem, p. XVII).

Os argumentos são os meios que dizem respeito à razão, sendo de duas espécies: aqueles que se inserem no "raciocínio silogístico" (entimemas) e aqueles que se baseiam 
no "exemplo". Não obstante, os meios que dizem respeito à afetividade são denominados de êthos e de páthos.

Há dois aspectos em que o persuasivo do discurso se insere: o "argumentativo" e o "oratório", aspectos esses não tão simples de se distinguir. Os gestos, o tom e as mudanças da voz do orador pertenceriam à parte da oratória. Reboul faz uma ressalta importante: "Todavia, o que dizer das figuras de estilo, aquelas famosas figuras a que alguns reduzem a retórica? A metáfora, a hipérbole, a antítese são oratórias por contribuírem para agradar ou comover, mas são também argumentativas no sentido de exprimirem um argumento condensando-o, tornando-o mais contundente" (ibidem, $p$. XVIII).

A outra função da retórica é a função hermenêutica ${ }^{16}$, pois a retórica é vista como a "arte de interpretar textos". O orador, para ser persuasivo, deve antes entender a retórica dos seus opositores e conhecer os seus pontos fracos.

Quando se utiliza a retórica para saber, para se encontrar algo, então, denominase função heurística ${ }^{17}$, que é a terceira função da retórica, uma vez que é uma função de "descoberta".

Como pois achar o verossímil? Recordaremos aqui a lei fundamental da retórica: o orador nunca está sozinho. O advogado mais hábil tem diante de si outros advogados que fazem o mesmo trabalho sem sentido inverso. Do mesmo modo, o político confronta outros políticos; o pedagogo, outros pedagogos. Cada um deles - essa é a regra do jogo defende sua causa sendo tão persuasivo quanto possível, e contribui assim para uma decisão que não lhe pertence, que incumbe a um terceiro: o juiz. Num mundo sem evidência, sem demonstração, sem previsão certa, em nosso mundo humano, o papel da retórica, ao defender esta ou aquela causa, é esclarecer aquele que deve dar a palavra final. Contribui - onde não há decisão, previamente, escrita para inventar uma solução. A retórica, realmente, possui uma função de descoberta (REBOUL, 2004, p. XX-XXI).

E, por fim, ensinar a compor de acordo com um plano, fazer a ligação, coerentemente, dos argumentos, cuidar do estilo, empregar as construções adequadas, a

${ }^{16} \mathrm{O}$ vocábulo hermenêutica provém do radical nominal de ermeneús, "intérprete" + sufixo nominal formador de adjetivos triforme -ikós, -iké, -ikón, que indicam aptidão, a capacidade de executar uma ação, isto é, "apto para interpretar, para explicar". É bom lembrar que ermeneús está vinculado, etimologicamente, ao deus Hermés, "Hermes", o mensageiro dos deuses.

${ }^{17} \mathrm{O}$ vocábulo heurística provém do radical verbal de heurísko, "encontro, descubro" + sufixo nominal formador de adjetivos triforme -ikós, -iké, -ikón, que indicam aptidão, a capacidade de executar uma ação, isto é, "apto para encontrar, para descobrir". 
falar de modo distinto etc., seria a competência da quarta função da retórica, a função pedagógica (ibidem, p. XXII).

\section{BIBLIOGRAFIA}

AESCHYLUS. Eumenides. Ed. of Herbert Weir Smyth. London: William Heinemann,

Ltd. $1926 . \quad$ Disponível em:

http://www.perseus.tufts.edu/hopper/text?doc=Perseus:text:1999.01.0005. Acesso em: $29 / 06 / 2013$.

AGOSTINHO. A Doutrina Cristã (Manual de Exegese e Formação Cristã). Tradução de Nair de Assis Oliveira. São Paulo: Paulus, 2002.

ALEXANDRE JÚNIOR, Manuel. Aristóteles: Retórica. Prefácio e Introdução de Manuel Alexandre Júnior. Centro de Filosofia da Universidade de Lisboa. Imprensa Nacional - Casa da Moeda: Lisboa, 2005. Disponível em: sumateologica.files.wordpress.com/2009/07/aristoteles_-_retorica2.pdf. Acesso em: Acesso em: 29 /10/ 2012.

ARISTOTE. Rhétorique. Texte Établi et Traduit par Médéric Dufour. Paris: Les Belles Lettres, 1967, Tome Premier.

Poétique. Texte Établi et Traduit par J. Hardy. Paris: Les Belles Lettres, 1979.

BAILLY, Anatole. Dictionnaire Grec-Français. Ed. Revista par L. Séchan e Chantraine. Paris: Hachette, 2000.

BENVENISTE, Émile. O Homem na Linguagem. Tradução de Isabel Maria Lucas Pascoal. Lisboa: Vega, s/d.

BÍBLIA HEBRAICA. Baseada no Hebraico e à Luz do Talmud e das Fontes Judaicas. Tradução de David Gorodovits e Jairo Fridlin. São Paulo: Sêfer, 2012. 
CHARAUDEAU, Patrick. Linguagem e Discurso: Modos de Organização. Tradução de Ângela M. S. Corrêa e Ida Lúcia Machado. São Paulo: Contexto, 2010.

CICERO, M. Tullius. Timaeus. Orator. Ed. of A. S. Wilkins. Oxonii. e Typographeo Clarendoniano. 1911. Disponível em: http://www.perseus.tufts.edu/hopper/text?doc=Perseus:text:2008.01.0545. Acesso em: $15 / 05 / 2013$.

CICÉRON. L'Orateur. Texte Établi et Traduit par Henri Bornecque. Paris: Les Belles Lettres, 1921.

. De L'Orateur (De Oratore). Texte Établi et Traduit et Annoté par François Richard (Livre I). Paris: Libraire Garnier Frères, s/d.

De L' Orateur. Texte Établi et Traduit par Edmond Courbaud (Livre II) Paris: Les Belles Lettres, 1959.

COLOMBANI, María Cecilia. De La Palavra Mágico-Religiosa, A La Palabra Política. Uma Lectura Desde Las Condiciones de Producción y Recepción Del Discurso. Phoînix. Rio de Janeiro: Mauad Editora, pp. 244-258, 2002.

DETIENNE, Marcel. Comparar o Incomparável. Tradução de Ivo Storniolo. São Paulo: Ideias e Letras, 2004.

EURIPIDES. Hippolytus. Ed. of David Kovacs. Cambridge. Harvard University Press. Forthcoming, s/d. Disponível em: http://www.perseus.tufts.edu/hopper/text?doc=Perseus:text:1999.01.0105. Acesso em 13/07/2013.

FLORESCU, Vasile. La Rhétorique et la Néorhétorique. Paris: Les Belles Lettres, 1982.

HOMER. Odyssey. Ed. of A.T. Murray. Cambridge, Massachusetts; Harvard University Press, 1919.

Disponível em: 
http://www.perseus.tufts.edu/hopper/text?doc=Perseus\%3Atext\%3A1999.01.0135\%3A book\%3D10\%3Acard\%3D503. Acesso em: 21 /06/ 2013.

HOMÈRE. Iliade. Texte Établi et Traduit par Paul Mazon (Tome 1, Chants I à XII). Paris: Société D’ Édition Les Belles Lettres, 1937.

HOMERO. Ilíada (Volume I). Tradução de Haroldo de Campos. São Paulo: Arx, 2003. Ilíada (Volume II). Tradução de Haroldo de Campos. São Paulo: Arx, 2002.

ISOCRATES. Against the Sophists. Ed. of George Norlin. London: William Heinemann Ltd 1980. Disponível em: http://www.perseus.tufts.edu/hopper/text?doc=Perseus\%3Atext\%3A1999.01.0144\%3As peech\%3D13. Acesso em: 19/07/2013.

Antidosis. Ed. of George Norlin. Cambridge, MA, Harvard University Press; London, William Heinemann Ltd. 1980. Disponível em: http://www.perseus.tufts.edu/hopper/text?doc=Perseus\%3Atext\%3A1999.01.0143\%3As peech\%3D15\%3Asection\%3D253. Acesso em: 10/10/2013.

LAUSBERG, Heinrich. Elementos de Retórica Literária. Tradução de R. M. Rosado Fernandes. Lisboa: Fundação Calouste Gulbenkian, 1967.

MARROU, Henri-Irénée. História da Educação na Antiguidade. Tradução de Mário Leônidas Casanova. São Paulo: Herder, 1969.

MOLINIÉ, Georges. Dictionnaire de Rhétorique. Paris: Librairie Générale Française, 1992.

PEREIRA, Maria Helena da Rocha. Estudos de História da Cultura Clássica. Lisboa: Fundação Calouste Gulkbenkian, 1993.

PERELMAN, Chaïm. Retóricas. Tradução de Maria Ermantina de Almeida Prado Galvão. São Paulo: Martins Fontes, 2004. 
Chaïm, OLBRECHTS-TYTECA, Lucie. Tratado da Argumentação: A

Nova Retórica. Tradução de Maria Ermantina de Almeida Prado Galvão. São Paulo: Martins Fontes, 2005.

PETERLINI, Ariovaldo Augusto. A Retórica na Tradição Antiga. In: MOSCA, Lineide do Lago Salvador (Org.). Retóricas de Ontem e de Hoje. São Paulo: Associação Editorial Humanitas, 2004, pp. 119- 144.

QUINTILIEN. Institution Oratoire. Texte Établi et Traduit par Jean Cousin (Tome II, Livres II et III). Paris: Les Belles Lettres, 1976.

REBOUL, Olivier. Introdução à Retórica. Tradução de Ivone Castilho Benedetti. São Paulo: Martins Fontes, 2004.

ROHDEN, Luiz. O Poder da Linguagem - A Arte Retórica de Aristóteles. Porto Alegre: EDIPUCRS, 1997.

ROMILLY, Jacqueline de. Fundamentos de Literatura Grega. Tradução de Mário da Gama Kury. Rio de Janeiro: Zahar Editores, 1980.

Homero, Introdução aos Poemas Homéricos. Tradução de Leonor SantaBárbara. Lisboa: Edições 70, 2001.

SOPHOCLES. Philoctetes. Ed. of Francis Storr. New York: William Heinemann Ltd., 1913. Disponível em: http://www.perseus.tufts.edu/hopper/text?doc=Perseus:text:1999.01.0193. Acesso em: 10/07/2013.

TERTUlliAN. Prescription Against Heretics. Ed. of Alexander Roberts, James Donaldson, and A. Cleveland Coxe. Buffalo, NY: Christian Literature Publishing Co., 1885. Disponível em: http://www.newadvent.org/fathers/0311.htm. Acesso em: $11 / 08 / 2013$. 
THUCYDIDE. La Guerre du Péloponnèse. Texte Établi et Traduit par Jacqueline de Romilly (Livre I). Paris: Les Belles Lettres, 1968.

La Guerre du Péloponnèse. Texte Établi et Traduit par Jacqueline de Romilly (Livre II). Paris: Les Belles Lettres, 1967. 